\title{
Identification of Distress Levels in Pregnant Women: A Descriptive and Cross-Sectional Study
}

\section{Gebelerin Distres Düzeylerinin Belirlenmesi: Tanımlayıcı ve Kesitsel Bir Çalışma}

\author{
Meltem Akbas $^{1^{*}}$, Sirin Celikkanat ${ }^{2}$, Sule Gokyildiz Surucu ${ }^{3}$
}

\begin{abstract}
Objectives: The purpose of the study is to identify distress levels and the affecting factors in pregnant women. Methods: This study was conducted in the Non-Stress Test unit of a Maternity and Children Hospital between $1^{\text {st }}$ and $31^{\text {st }}$ of March, 2017 in Turkey. This study is descriptive and cross-sectional. The participants were 250 pregnant women who met the research criteria and volunteered to participate in the study. Data were collected using the "Socio-demographic Form" and "Tilburg Pregnancy Distress Scale". Analysis of the data was performed using percentages, means, student t-test, ANOVA, and Linear Regression. Results: The average age of pregnant women was 26.73. Of all the participants, $52.2 \%$ graduated from primary school, $93.5 \%$ did not work, $79.6 \%$ had social security, partners of $43.3 \%$ were workers, $74.7 \%$ had medium financial level, $79.6 \%$ had a nuclear family, $66.1 \%$ experienced their first pregnancy, $90,6 \%$ had planned their pregnancy, and $64.9 \%$ had a living child. The mean score for the total scale was $23.54 \pm 7.590$; mean score for the negative effect subscale was $20.81 \pm 6.560$, and mean score for the partner involvement sub-scale was $2.73 \pm 2.967$. According to the cut-off point, $25.3 \%$ of pregnant women were found to be distressed. Conclusions: This study found that approximately one-fourth of the pregnant women were distressed, which was considered to result from their socio-demographic and obstetric features. A holistic approach should be applied to pregnant women in their pregnancy follow-ups considering their psychological needs as well as physiological and biological ones.
\end{abstract}

Key words: Pregnancy, distress, anxiety, depression

\section{ÖZET}

Amaç: Çalışmamızın amacı gebelerde distres düzeyinin belirlenmesidir. Yöntem: Çalışma tanımlayıcı ve kesitsel tipte yapılmıştır. Çalışmaya alınma kriterlerine uyan ve çalışmaya gönüllü olarak katılan 250 gebe araştırmanın örneklemini oluşturmuştur. Veriler "Kişisel Bilgi Formu" ve "Tilburg Gebelikte Distres Ölçeği” kullanılarak toplanmıștır. Verilerin değerlendirilmesinde; Yüzde, Ortalama, Student t testi ve ANOVA ve Linear Regresyon kullanılmıştır. Bulgular: Gebelerin; yaş ortalamasının 26,94 $\pm 5,73$ olduğu, \% 52,2'sinin ilkokul mezunu olduğu, \%93,5'inin çalışmadığı, \%79,6'sının sosyal güvencesinin olduğu, \% 43,3'ünün eşinin işci olduğu, \%74,7'sinin ekonomik durumunun orta düzeyde olduğu, \%79,6'sının çekirdek aileye sahip olduğu, \%66,1'inin ilk gebeliği olmadığ1, \%90,6'sının isteyerek gebe kaldığı, \%64,9'unun yaşayan çocuğu olduğu saptanmıştır. Gebelerin toplam ölçek puan ortalamasının $-23,54 \pm 7,590$, olumsuz duygulanım

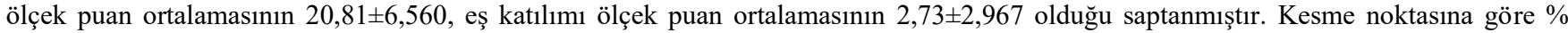
25.3'ünün streste olduğu saptanmıştır. Sonuç: Çalışmadan elde edilen bulgulara göre, gebelerin yaklaşık dörtte birinin distreste olduğu görülmektedir. Gebeler sadece fizyolojik ve biyolojik gereksinimler açıdan değil psikolojik gereksinimleri de göz önüne alınarak, gebelik takiplerine bütüncül yaklaşılmalıdır.

Anahtar kelimeler: Gebelik, distres, anksiyete, depresyon

Received / Geliş tarihi: 06.03.2020, Accepted / Kabul tarihi: 22.04.2020

${ }^{1}$ Cukurova University, Faculty of Health Sciences, Department of Midwifery, ADANA

${ }^{2}$ Cukurova University, Faculty of Health Sciences, Department of Midwifery, ADANA

${ }^{3}$ Cukurova University, Faculty of Health Sciences, Department of Midwifery, ADANA

*Address for Correspondence / Yazışma Adresi: Meltem Akbaş, Çukurova Üniversitesi Sağlık Bilimleri Fakültesi, 01330 Sarıçam/ADANA-TÜRKIYE,

E-mail: makbaskanat@gmail.com

Akbas M, Celikkanat S, Surucu Gokylldız S. Identification of Distress Levels in Pregnant Women: A Descriptive and Cross-Sectional Study. TJFMPC, 2020;14(3): 362-367.

DOI: $10.21763 / \mathrm{tjfmpc} .699627$ 


\section{INTRODUCTION}

Besides being a physiologic process with important biological changes, pregnancy and labor is a complicated psychological state in which suppressed and unsolved conflicts regarding early development periods reawaken. ${ }^{1}$ While a lot of women easily adapt pregnancy and birth-related physiological, psychological, and social changes; some women experience mild, medium, or high levels of psychological problems. ${ }^{2}$ Unlike the general belief, pregnancy is not always joyful or successful. Most women experience sorrow, anxiety, and depression in this period. Depression is the most common psychological disorder during pregnancy. ${ }^{3}$ Low income, young age, low education level, and lack of social support increase risks during pregnancy. ${ }^{4}$ Depression risk increases throughout pregnancy, especially in the second and third trimesters. A number of studies report that depressive symptoms are experienced more during pregnancy in comparison to the postpartum period. A meta-analysis reported depression prevalence as $7.4 \%$ in the first trimester, $12.8 \%$ in the second trimester, and $12 \%$ in the third trimester. ${ }^{5}$ Various studies that investigated depression prevalence during pregnancy in different cultures showed that prevalence of symptoms was $17.9 \%$ in Hungary, $20 \%$ in the United States of America, 25\% in Canada, and $30 \%$ in Finland. ${ }^{6}$ Report for our country indicate the prevalence of anxiety as $12 \%$ to $34 \%$ and prevalence of depression as $19 \%$ to $53 \%{ }^{7} \quad$ Stress, depression or anxiety in the pregnancy period do not affect woman's life and health only; they also increase obstetric complications (fetus's growth deficiency, preterm labor, low birth weight). ${ }^{8}$ Anxiety, depression, and stress in pregnancy are risk factors for adverse outcomes for mothers and children. It is reported in a study that pregnant women who experience negative affect have the risk of having preterm labor and low-birth-weight baby. ${ }^{9}$ Several screening instruments have been validated for use during pregnancy and postpartum period to assist with systematically identifying patients with perinatal depression. ${ }^{10}$ The Edinburg Postnatal Depression Scale (EPDS) is most frequently used in the research setting and clinical practice for several reasons. Other screening instruments are Patient Health Questionnaire 9, Beck Depression Inventory, Center for Epidemiologic Studies Depression Scale and Zung Self Rating Depression Scale. ${ }^{10}$

Health services have traditionally focused on postpartum depression. However, studies today have begun to focus on risks associated with prenatal psychological distress. Assessment of psychological distress experienced during pregnancy has gained importance. Some industrialized countries have developed prenatal screening protocols that evaluate anxiety and depression and psychological variables. ${ }^{11}$

The pregnant woman and the fetus are going through a healthy process depends on the woman's well-being in terms of physiological, biological, and psychological aspects. The psychological state of the pregnant woman affects all these variables. The purpose of this study is to identify distress levels and the affecting factors in pregnant women.

\section{METHODS}

\section{Study Design}

This study is descriptive and cross-sectional.

\section{Setting}

This study was conducted in the Non-Stress Test (NST) Unit of a Maternity and Children Hospital between $1^{\text {st }}$ and $31^{\text {st }}$ of March 2017. This hospital was chosen because of being a branch hospital with high capacity. NST Unit is a polyclinic that examines the fetal heart rate (FHR) and performs the non-stress test. Due to the high number of patients in the polyclinics where antenatal followups were performed in the hospital the study was conducted, the pregnant women are routinely referred to the NST unit for FHR.

\section{Target Population and Sample}

The target population of the study was all pregnant women who applied to the NST unit between $1^{\text {st }}$ and $31^{\text {st }}$ of March 2017. The average number of pregnant women applying this unit per month is about 2500. The study involved pregnant women who completed $12^{\text {th }}$ gestational week, who were not diagnosed with a risky pregnancy or psychological complaint by the doctor during antenatal visits, who could speak Turkish, and whose health status did not prevent them from participating in the study. The participants were 250 pregnant women who met the research criteria and volunteered to participate in the study. 22 pregnant women refused to participate in the study because they reportedly had no time; 48 women who were diagnosed with risky pregnancy by the doctor were excluded from the study.

\section{Data Collection}

Data were collected through the "Sociodemographic Form" and "Tilburg Pregnancy Distress Scale". Socio-demographic form, which was developed by the researchers in line with the related literature, contained 12 questions regarding women's demographic and obstetric features. Tilburg pregnancy distress scale was developed by Victor et al. in Netherlands in 2011 with a view to 
identifying pregnant women's distress levels. Turkish reliability and validity of the scale was performed by Pasinlioglu and Capik in 2015. ${ }^{11}$ The 4-point Likert type scale has 16 items. The scale is scored as " $0=$ very often", 1= "quite often", 2= "sometimes", 3= "rarely or never". Scores to be taken from the scale range between 0 and 48 . The scale has two sub-scales called "Negative affect" and "Partner involvement". Negative affect subscale is composed of 11 items, which include Item $3,5,6,7,9,10,11,12,13,14$, and 16 . Scores to be taken from these sub-scales range between 0 and 33. Partner involvement subscale is composed of 5 items, which include Item 1, 2, 4, 8, and 15. Scores to be taken from these sub-scales range between 0 and 15. The scale is administered to pregnant women who are in 12 and more weeks of gestation. The cut-off point for the scale is 28.00 for the total score, 10.00 for the partner involvement sub-scale, and 22.00 for the negative effect sub-scale. Total scores over this cut-off point enable to identify women who are under risk in terms of distress (depression, anxiety, stress). Cronbach's alpha coefficients were 0.83 for the total scale, 0.72 for the partner involvement sub-scale, and 0.83 for the negative effect sub-scale. ${ }^{11}$ Data in this study were collected through face to face interview technique, which took approximately 10 minutes.

\section{Statistical Analysis}

Data were analyzed using SPSS 20.0 (Statistical Package for the Social Sciences) program using descriptive and parametric statistical analysis methods. Descriptive statistical analyses involved the calculation of means, standard deviations, frequencies, and minimum and maximum values. Comparisons were performed using t-test for the comparisons of two groups, and One-way ANOVA test for the comparison of three and more groups. Linear regression analysis was performed in order to find out which independent variables affected the dependent variable more. The statistical significance level was taken 0.05 .

Table 1- Descriptive features of the pregnant women $(\mathrm{n}=250)$.

\begin{tabular}{lll}
$(\mathrm{n}=250)$. & \\
$\begin{array}{l}\text { Socio-demographic } \\
\text { Features }\end{array}$ & $\mathbf{n}$ & $\mathbf{\%}$ \\
\hline Age & & 12.7 \\
20 and younger & 31 & 74.3 \\
$21-34$ & 182 & 13.1 \\
35 and over & 32 &
\end{tabular}

\begin{tabular}{|c|c|c|}
\hline \multicolumn{3}{|l|}{ Education Level } \\
\hline Primary School & 128 & 52.2 \\
\hline $\begin{array}{l}\text { Secondary school and } \\
\text { over }\end{array}$ & 117 & 47.8 \\
\hline \multicolumn{3}{|l|}{ Employment Status } \\
\hline Employed & 16 & 6.5 \\
\hline Unemployed & 229 & 93.5 \\
\hline \multicolumn{3}{|l|}{ Social Security } \\
\hline Yes & 195 & 79.6 \\
\hline No & 50 & 20.4 \\
\hline \multicolumn{3}{|l|}{ Partner's Profession } \\
\hline Worker & 111 & 43.3 \\
\hline Civil servant & 42 & 17.1 \\
\hline Self-employed & 92 & 37.6 \\
\hline \multicolumn{3}{|l|}{ Financial Level } \\
\hline Good & 48 & 19.6 \\
\hline Medium & 183 & 74.7 \\
\hline Low & 14 & 5.7 \\
\hline \multicolumn{3}{|l|}{ Family Type } \\
\hline Nuclear Family & 195 & 79.6 \\
\hline Extended Family & 50 & 20.4 \\
\hline \multicolumn{3}{|l|}{ First pregnancy } \\
\hline Yes & 83 & 33.9 \\
\hline No & 162 & 66.1 \\
\hline \multicolumn{3}{|l|}{ Wanting the Pregnancy } \\
\hline Yes & 222 & 90.6 \\
\hline No & 23 & 9.4 \\
\hline \multicolumn{3}{|l|}{ Having a Living Child } \\
\hline Yes & 159 & 64.9 \\
\hline No & 86 & 35.1 \\
\hline
\end{tabular}

\section{RESULTS}

Table 1 demonstrates findings in relation to the descriptive features of pregnant women. Of all the participating pregnant women, $74.3 \%$ were aged between 21 and 34, 52.2\% graduated from primary school, 93.5\% did not work, $79.6 \%$ had social security, $43.3 \%$ had a partner who is a worker, $74.7 \%$ had medium financial level, $79.6 \%$ had a nuclear family, $66.1 \%$ did not have their first pregnancy, $90.6 \%$ wanted to get pregnant, and $64.9 \%$ had a living child (see Table 1 ). The average age of pregnant women was $26.94 \pm 5.73$.

The participating pregnant women's Tilburg Distress Scale and sub-scale mean scores are given in Table 2. Distribution of the participants according to the Tilburg Distress Scale cut-off point showed that $25.3 \%(n=62)$ were distressed. Tilburg Distress Scale total mean score of the women who were distressed was found $32.31 \pm 0.428$. 
Table 2- Pregnant women's Tilburg Distress Scale and sub-scale mean scores $(n=250)$

\begin{tabular}{llll}
\hline $\begin{array}{l}\text { Scale and } \\
\text { Sub-scales }\end{array}$ & $\begin{array}{l}\text { Item } \\
\text { Number }\end{array}$ & Mean \pm SD & $\begin{array}{l}\text { Expected } \\
\text { Distribution } \\
\text { Range }\end{array}$ \\
\hline $\begin{array}{l}\text { Total Scale } \\
\text { Negative }\end{array}$ & 16 & $23.54 \pm 7.590$ & $0-41$ \\
$\begin{array}{l}\text { Affect } \\
\text { Partner }\end{array}$ & 11 & $20.81 \pm 6.560$ & $0-33$ \\
Involvement & 5 & $2.73 \pm 2.967$ & $0-15$ \\
\hline
\end{tabular}

Table 3 demonstrates the pregnant women's Tilburg Distress Scale total and sub-scale means according to various variables. Tilburg Distress Scale total score, negative affect, and partner involvement sub-scale mean scores did not demonstrate differences according to the women's education level, employment status, and the partner's profession $(\mathrm{p}>0.05)$. While the total score and partner involvement sub-scale demonstrated difference according to the participants' first pregnancy $(p<0.05)$, negative affect sub-scale indicated no significant differences $(p>0.05)$. A significant difference was found between the family type, planning the pregnancy and partner involvement sub-scale mean score, statistically $(\mathrm{p}<0.05)$. An analysis of the Tilburg Distress Scale total mean score according to the participants' financial level showed that those who reported having the low financial level had lower scores, and there was a significant difference between them $(p<0.05)$ (see Table 3$)$.

Linear regression analysis performed with a view to finding out which variables affected pregnant women's distress levels showed that the pregnant women's distress level was not affected by age, education level, financial level, number of living children, wanting the pregnancy, and having the first pregnancy.

\section{DISCUSSION}

Of all the participating pregnant women, $74.3 \%$ were aged between 21 and 34, and the average age was 26.94. According to Turkish Population and Health Research (TPHR) 2013 data, fertility rate specific to highest age was in the 25-29 age group. ${ }^{12}$ The present study demonstrates similarity with the TPHR data; young adulthood period seems to be the age for motherhood.

An analysis of the pregnant women's Tilburg Distress Scale mean score indicated that total mean score was 23.54 , negative affect subscale was 20.81 , and the partner involvement sub-
Table 3- Distribution of pregnant women's Tilburg Distress Scale total and sub-scale mean scores according to some variables $(\mathrm{n}=250)$

\begin{tabular}{|c|c|c|c|c|c|}
\hline $\begin{array}{l}\text { Tilburg } \\
\text { Distress } \\
\text { Scale } \\
\text { Features of } \\
\text { the } \\
\text { Participant } \\
\text { s }\end{array}$ & $\mathbf{n}$ & $\%$ & Total & $\begin{array}{l}\text { Negative } \\
\text { Affect }\end{array}$ & $\begin{array}{l}\text { Partner } \\
\text { Involveme } \\
\text { nt }\end{array}$ \\
\hline \multicolumn{6}{|c|}{ Education Level } \\
\hline $\begin{array}{l}\text { Primary } \\
\text { school }\end{array}$ & 128 & 52.2 & $23.69 \pm 8.11$ & $20.54 \pm 6.87$ & $3.15 \pm 3.12$ \\
\hline $\begin{array}{l}\text { Secondary } \\
\text { school and } \\
\text { beyond }\end{array}$ & 117 & 47.8 & $23.39 \pm 7.00$ & $21.12 \pm 6.21$ & $2.72 \pm 0.25$ \\
\hline$t$ value & & & 0.303 & -0.691 & 2.326 \\
\hline $\mathrm{p}$ value & & & 0.762 & 0.490 & 0.21 \\
\hline \multicolumn{6}{|c|}{ Employment Status } \\
\hline Employed & 16 & 6.5 & $21.0 \pm 8.03$ & $18.69 \pm 6.57$ & $2.31 \pm 3.02$ \\
\hline $\begin{array}{l}\text { Unemployed } \\
\text { t value } \\
\text { p value }\end{array}$ & 229 & 93.5 & $\begin{array}{l}23.72 \pm 7.54 \\
-1.391 \\
0.165\end{array}$ & $\begin{array}{l}20.97 \pm 6.64 \\
-1.345 \\
0.180\end{array}$ & $\begin{array}{l}2.76 \pm 2.96 \\
-0.582 \\
0.561\end{array}$ \\
\hline \multicolumn{6}{|c|}{ First Pregnancy } \\
\hline Yes & 83 & 33.9 & $21.81 \pm 7.80$ & $20.02 \pm 7.07$ & $1.78 \pm 2.08$ \\
\hline $\begin{array}{l}\text { No } \\
\text { t value } \\
p \text { value }\end{array}$ & 162 & 66.1 & $\begin{array}{l}24.44 \pm 7.34 \\
-2.598 \\
\mathbf{0 . 0 1 0}\end{array}$ & $\begin{array}{l}21.22 \pm 6.26 \\
-1.355 \\
0.177\end{array}$ & $\begin{array}{l}3.22 \pm 3.23 \\
-3.668 \\
\mathbf{0 . 0 0 0}\end{array}$ \\
\hline \multicolumn{6}{|l|}{ Family Type } \\
\hline $\begin{array}{l}\text { Nuclear } \\
\text { Family }\end{array}$ & 195 & 79.6 & $23.83 \pm 7.21$ & $21.34 \pm 6.31$ & $2.49 \pm 2.74$ \\
\hline $\begin{array}{l}\text { Extended } \\
\text { Family }\end{array}$ & 50 & 20.4 & $22.44 \pm 8.91$ & $18.78 \pm 7.14$ & $3.66 \pm 3.60$ \\
\hline t value & & & 1.157 & 2.486 & -2.509 \\
\hline $\mathrm{p}$ value & & & 0.249 & 0.014 & 0.013 \\
\hline \multicolumn{6}{|c|}{ Having Wanted to Get Pregnant } \\
\hline Yes & 222 & 90.6 & $23.63 \pm 7.73$ & $21.09 \pm 6.66$ & $2.55 \pm 2.77$ \\
\hline $\begin{array}{l}\text { No } \\
\text { t value } \\
\text { P value } \\
\text { Having a Liv }\end{array}$ & $\lg \mathrm{Ch}$ & 9.4 & $\begin{array}{l}22.74 \pm 6.04 \\
0.535 \\
0.593\end{array}$ & $\begin{array}{l}18.22 \pm 4.88 \\
2.008 \\
\mathbf{0 . 0 4 6}\end{array}$ & $\begin{array}{l}4.52 \pm 4.10 \\
-3.094 \\
\mathbf{0 . 0 0 2}\end{array}$ \\
\hline Yes & 159 & 64.9 & $24.56 \pm 7.26$ & $21.28 \pm 6.19$ & $3.28 \pm 3.22$ \\
\hline No & 86 & 35.1 & $21.67 \pm 7.86$ & $19.95 \pm 7.14$ & $1.72 \pm 2.07$ \\
\hline t value & & & 2.882 & 1.518 & 4.038 \\
\hline $\mathrm{p}$ value & & & 0.004 & 0.130 & 0.000 \\
\hline \multicolumn{6}{|c|}{ Partner's Profession } \\
\hline Worker & 111 & 43.3 & $24.29 \pm 7.71$ & $21.58 \pm 6.67$ & $2.71 \pm 3.01$ \\
\hline $\begin{array}{l}\text { Civil } \\
\text { Servant }\end{array}$ & 42 & 17.1 & $22.57 \pm 8.71$ & $19.79 \pm 7.05$ & $2.79 \pm 3.41$ \\
\hline $\begin{array}{l}\text { Self- } \\
\text { employed }\end{array}$ & 92 & 37.6 & $23.10 \pm 6.85$ & $20.37 \pm 6.13$ & $2.73 \pm 2.66$ \\
\hline$F$ value & & & 1.038 & 1.483 & 0.009 \\
\hline $\mathrm{p}$ value & & & 0.356 & 0.229 & 0.991 \\
\hline \multicolumn{6}{|c|}{ Financial Level } \\
\hline Good & 48 & 19.6 & $22.33 \pm 7.94$ & $20.19 \pm 7.10$ & $2.15 \pm 2.97$ \\
\hline Medium & 183 & 74.7 & $24.23 \pm 7.31$ & $21.26 \pm 6.31$ & $2.97 \pm 2.95$ \\
\hline Low & 14 & 5.7 & $18.79 \pm 8.27$ & $17.14 \pm 6.98$ & $1.64 \pm 2.79$ \\
\hline $\mathrm{F}$ value & & & 4.216 & 2.882 & 2.485 \\
\hline $\mathrm{p}$ value & & & 0.016 & 0.058 & 0.085 \\
\hline
\end{tabular}

scale was 2.73. Capik et al. ${ }^{11}$ found the mean scores as 18.86 for total scale, 13.64 for the negative effect sub-scale, and 5.22 for the partner involvement subscale. Tilburg Distress Scale and sub-scale mean scores were found to be different from those of Capik et al. ${ }^{11}$ mean scores were higher in the present study, which was riskier in terms of distress. No similarities were found between the present study and the study conducted by Capik et al. ${ }^{11}$. According to the cut-off point of the scale, $25.3 \%$ of the participants were found to experience distress (anxiety, depression). In the study 
conducted by Bekele et al. ${ }^{13}$, presence of distress was found $26.2 \%$; pregnancy stress was found $28.6 \%$ in the study conducted by Boakye-Yiadom et al. ${ }^{14}$. The findings of the present study are in line with those studies. However, the related literature encompasses studies that do not support our findings. Bisetegn et al. ${ }^{15}$ reported that $11.8 \%$ of the pregnant women demonstrated depressive symptoms during pregnancy. Pereira et al. ${ }^{16}$ found pregnancy depression as $14.2 \%$; Cakir and $\mathrm{Can}^{17}$ found anxiety as $34.1 \%$ and depression as $32.4 \%$ among pregnant women. This study found significant differences between Tilburg distress scale total mean score and experiencing pregnancy first time, having a living child, and a financial level. The distress score was found to be higher in those who had a living child, who had medium financial level, and who did not have their first pregnancy. Jonsdottir et al. ${ }^{18}$ found significant An analysis of the pregnant women's Tilburg Distress Scale mean score indicated that total mean score was 23.54 , negative affect sub-scale was 20.81 , and the partner involvement sub-scale was 2.73. Çapik et al. ${ }^{11}$ found the mean scores as 18.86 for total scale, 13.64 for the negative effect sub-scale, and 5.22 for the partner involvement sub-scale. Tilburg Distress Scale and sub-scale mean scores were found to be different from those of Capik et al. ${ }^{11}$ mean scores were higher in the present study, which was riskier in terms of distress. No similarities were found between the present study and the study conducted by Capik et al. ${ }^{11}$. According to the cut-off point of the scale, 25.3\% of the participants were found to experience distress (anxiety, depression). In the study conducted by Bekele et al. ${ }^{13}$, presence of distress was found $26.2 \%$; pregnancy stress was found $28.6 \%$ in the study conducted by Boakye-Yiadom et al. ${ }^{14}$. The findings of the present study are in line with those studies. However, the related literature encompasses studies that do not support our findings. Bisetegn et al. ${ }^{15}$ reported that $11.8 \%$ of the pregnant women demonstrated depressive symptoms during pregnancy. Pereira et al. ${ }^{16}$ found pregnancy depression as 14.2\%; Cakir and $\mathrm{Can}^{17}$ found anxiety as $34.1 \%$ and depression as $32.4 \%$ among pregnant women. This study found significant differences between Tilburg distress scale total mean score and experiencing pregnancy first time, having a living child, and a financial level. The distress score was found to be higher in those who had a living child, who had medium financial level, and who did not have their first pregnancy. Jonsdottir et al. ${ }^{18}$ found significant differences between the groups who were distressed and who were not in terms of education, employment status and income level. Yilmaz and Bej1 ${ }^{19}$ reported that pregnant women who had low education level, who did not have planned pregnancy, and who were at low socio-economic level demonstrated more depressive symptoms. Tandu-Umba et al. ${ }^{20}$ compared pregnant women who were stressed and who were not and found that those who graduated from primary school, who did not have a planned pregnancy, and who were at low socio-economic level demonstrated significant differences (more stressed). Finally, Tekgoz et al. ${ }^{21}$ found significant differences between financial level and anxiety; no significant differences were found between having a planned pregnancy and employment status. Only the financial factors demonstrated similarities between the present study and other studies.

\section{Limitation}

The study was limited with pregnant women who applied to the NST unit of a Maternity and Children Hospital between 1st and 31st of March, 2017.

\section{CONCLUSION}

This study found that approximately one-fourth of the pregnant women were distressed, which was considered to result from socio-demographic and obstetric features. Given that depressive psychology affects the health of the pregnant woman, fetus, new-born, and family in a negative way;

- Pregnant women should be approached in a holistic way, not only physiologically and biologically but also in terms of their psychological needs.

- Doctors working in primary care health services should organize in-service training to doctors, midwives, and nurses with a view to protecting pregnant women's mental health.

Acknowledgments: We would like to thank all participants in the study.

Funding: This study is not supported financially.

Conflict of Interest: Authors declare that they have no conflict of interest.

Ethical Approval: Approval from Cukurova University Faculty of Medicine Non-Invasive Clinical Research Ethics Committee was obtained (with decision dated December, 2nd, 2016 and numbered 59/9), and permission from the hospitals and informed consent from the patients participating in the study were obtained. 


\section{REFERENCES}

1. Akbas E, Virit O, Kalenderoglu A, Savas AH, Sertbas G. Relation of socio demographic variables in pregnancy with anxiety and depression levels. Archives of Neuropsychiatry. 2008; 45, 85-91. Available from: http://www. noropsikiyatriarsivi.com/sayilar/386/buyuk/913.pdf, March 09, 2020.

2. Daglar G, Nur N. The relationship between anxiety and depression level and coping styles with stress of pregnant women. Cumhuriyet Medical Journal. 2014; 36(4): 429-441.

3. Bennett HA, Einarson A, Koren G, Einarson TR. Prevalence of Depression during Pregnancy: Sistematic Review. Obstet Gynecol. 2004; 103(4): 698-709.

4. Pereira P, Lovisi G, Lima L, Legay L, CintraSantos F, Santos S, et al. Depression during pregnancy: review of epidemiological and clinical aspect in developed and developing countries. Phsychiatric Disorder - Trends and developments InTech. 2011; 267-290.

5. Biratu A, Haile D. Prevalence of antenatal depression and associated factors among pregnant women in Addis Ababa, Ethiopia: a cross-sectional study. Reproductive Health. 2015; 12(1): 99.

6. Calik K, Aktas S. Depression in pregnancy prevalence, risk factors and treatment. Current Approaches in Psychiatry. 2011; 3(1): 142-162.

7. Daglar G, Nur N, Kadioglu M. Affective disorders in pregnancy. KASHED, 2015; 2(1):2740.

8. Pop VJM, Pommer AM, Pop-Purceleanu M, Wijnen HAA, Bergink V, Pauwer F. Development of the Tilburg pregnancy distress scale: the TPDS. BMC Pregnancy and Childbirth. 2011; 11(1): 80.

9. Schetter CD, Tanner L. Anxiety, depression and stress in pregnancy: implications for mothers, children, research, and practic. Curr Opin Psychiatry. 2012; 25(2): 141-148.

10. ACOG Committee Opinion. Number 757. Screening for perinatal depression. Obstetrics and Gynecology. 2018;132(5): e208-e212.

11. Capik, A, Apay S, Sakar T. Determination of The Level of Distress in Pregnant Women. Anadolu Journal of Nursing and Health Sciences. 2015; 18:3.
12. 2013 Hacettepe University institute of population studies. population and health survey. Ankara, Turkey: November 2014. (cited 2018 Nov 28). Available from: http://www.hips.hacettepe.edu.tr/eng/TDHS_2013_ main.report.pdf, March 09, 2020.

13. Bekele D, Worku A, Wondimagegn D. Prevalence and associated factors of mental distress during pregnancy among antenatal care attendees at saint paul's hospital, addis ababa. Obstetrics \& Gynecology International Journal. 2017; 7(6), 00269.

14. Boakye-Yiadom A, Sihuttu SO, Dutt JB, Dapare PPM, Alhassan A. Perceived stress and anxiety among ghanaian pregnant women. Journal of Medical and Biomedical Sciences. 2015; 4(2): 29-37.

15. Biseteng T, Mihretia G, Muche T. Prevalence and predictors of depression among pregnant women in debretabor town, northwest ethiopia. PloS one. 2016; 11(9): e0161108.

16. Pereira P. Lovisi G, Lima L, Legay L. Depression during pregnancy: prevalence and risk factors among women attending a public health clinic in rio de janeiro, brazil. Cadernos de Saúde Pública. 2009, 25(12), 2725-2736.

17. Cakir L, Can H. Relation between sociodemographic variables with the levels of depression and anxiety in pregnancy. Turkish Family Physician. 2011; 3(2): 35-42

18. Jonsdottir S, Thome M, Steingrimsdottir T, Lydsdottir L, Sigurdsson J, Olafsdottir H, et al. Partner Relationship, Social support and perinatal distress among pregnant Icelandic women. Women and Birth. 2017; 30(1): e46-e55.

19. Yilmaz S, Beji N. Levels of coping with stress, depression and prenatal attachment and affecting factors of pregnant women. Journal of General Medicine. 2010; 20(3): 99-108.

20. Tandu-Umba B, Dedetemo D, Mananga G. Maternal stress and pregnancy outcomes. Open Journal of Obstetrics and Gynecology. 2014; 4 (3): 61-370.

21. Tekgoz I, Sunay D, Caylan A, Kisa C. Assessment of anxiety disorders and related factors at the third trimester of pregnancy. Turkish Journal of Family Practice. 2009; 13(3): 132-136. 